\title{
FATHOM
}

\section{The Medusean Eye in Thomas Hardy}

L'oeil méduséen chez Thomas Hardy

\section{Annie Ramel}

\section{OpenEdition}

Journals

Electronic version

URL: http://journals.openedition.org/fathom/774

DOI: $10.4000 /$ fathom.774

ISSN: 2270-6798

\section{Publisher}

Association française sur les études sur Thomas Hardy

\section{Electronic reference}

Annie Ramel, «The Medusean Eye in Thomas Hardy », FATHOM [Online], 5 | 2018, Online since 22 April 2018, connection on 01 May 2019. URL : http://journals.openedition.org/fathom/774 ; DOI : 10.4000/ fathom. 774

This text was automatically generated on 1 May 2019. 


\title{
The Medusean Eye in Thomas Hardy
}

\author{
L'œil méduséen chez Thomas Hardy
}

\section{Annie Ramel}

\section{EDITOR'S NOTE}

This article is being published jointly by FATHOM and the Hardy Review as part of a collaborative work.

1 The eye in Thomas Hardy's fiction often appears as the "evil eye", an eye full of voracity, endowed with the Medusean power to petrify and to kill. An article written jointly by Phillip Mallett and Jacqueline Dillion offers a brilliant analysis of "the evil eye" in The Return of the Native, relating it to the superstition known in Dorset as "overlooking" (Dillion \& Mallett; see also Dillion 2016, and F.E. Hardy 268-269). I too have explored the question of the evil eye, mostly in Far from the Madding Crowd and The Return of the Native, in several articles (Ramel 2010a, 9, 26; Ramel 2010b, 91-92), and in my book on Hardy (Ramel 2015, 101-103). I fully agree with the reading provided by my two colleagues, but I tend to view things in a slightly different perspective, oriented by Lacanian psychoanalysis. Therefore I shall try in this article to bring something new to the debate on "overlooking", and throw some light on the questions raised by the weird power of "the evil eye" in Hardy's fiction.

\section{The eye and the gaze}

One point on which I (slightly) differ from my colleagues' analysis is the positive value they give to the "face-to-face encounter", the "shared humanity" and "ethical obligations" that go with it ${ }^{1}$. Indeed in Lacan's perspective, there can be no absolute faceto-face encounter, because structurally speaking "you never look at me from the place where I see you", and conversely "what I look at is never what I wish to see" (Lacan 1986, $103)^{2}$. If I saw what I really wish to see, that would mean reaching the object of my desire, 
that is to say putting an end to desire and thus to life. If the Other saw me at the innermost point from which I see him, such an intrusion would be deadly. Tess, as a sunray peers under her eye-lids and wakes her on Salisbury Plain (Hardy 1991, 381), is the victim of such an effraction. The gaze of the Other enters her and thus condemns her to death. As Joseph Hillis Miller writes:

The sun is in this novel, as in tradition generally, the fecundating male source, a principle of life, but also a dangerous energy able to pierce and destroy, as Tess, at the end of the novel, lying on the stone of sacrifice at Stonehenge, after her brief period of happiness with Angel, is wakened, just before her capture, by the first rays of the morning sun which penetrate under her eyelids (Miller 1982, 122).

3 The sun-beam, here, symbolizes the gaze of the Other that enters her, representing the social and Symbolic order that sentences her to death. On the contrary, in the non-tragic sub-plot of The Return of the Native, Thomasin is shielded from the Other's gaze by Venn, who has taken care to hang all the drapery in his possession around her couch (supposedly to keep her from any contact with the red material of his trade). Yet the invasive light of the lantern threatens to creep under her eye-lids when Mrs Yeobright is allowed into the van and shown the sleeping girl. One thing is sure: "she was not made to be looked at thus", and the reddleman "cast his eyes aside with a delicacy which well became him" (Hardy 1990, 36). The girl is protected from the "watchful intentness" (4) of gazers.

The Lacanian concept of "object-gaze" (objet-regard, often translated as "gaze qua object") is needed here to understand the fundamental dissymmetry between seeing and being seen. Sartre had posited a reciprocity between seeing the Other and being seen by him; Lacan, on the contrary, argued that there is a split between the eye, which is on the side of the subject, and the gaze, on the side of the object, that is to say on the side of the Other. Why this lack of coincidence? Why this unbridgeable gap? Because of subjective division, which means that the self is divided between itself and the semblance it shows to the world, "the paper tiger it shows to the other" (Lacan 1986, 107). Access to the Other is always missed, the wall of semblances divides the subject from the object of his desire, as the French poet Louis Aragon knew very well before Lacan developed his theory of the gaze:

In vain your image comes to meet me

And does not enter me where I am who only shows it

Turning towards me you can find

On the wall of my gaze only your dreamt-of shadow.

I am that wretch comparable with mirrors

That can reflect but cannot see

Like them my eye is empty and like them inhabited

By your absence which makes it blind. ${ }^{4}$

Blind, that is what every human being is, fundamentally: Lacan argues that the Biblical words "they have eyes that they might not see" speak some truth about the "antinomic way" between the two terms involved in the scopic field: the eye and the gaze.

A few words may be necessary here about the gaze as distinct from the eye, the gaze of the Other: Lacan's point is that, even before I start looking at the world around us, I am being looked at from everywhere: "I see only from one point, but in my existence I am looked at from all sides" (Lacan 1986, 72). Looked at, but not seen - for the Other's gaze cannot reach me. The example he gives is the sardine-tin which he remembers a fisherman pointed out to him when, as a young man, he was sailing with him in Brittany. 
The man exclaimed: "You see that can? Do you see it? Well, it does not see you!" (95). Lacan kept asking himself questions about those words because, he says, "if what PetitJean said to me, namely, that the can did not see me, had any meaning, it was because in a sense, it was looking at me all the same. It was looking at me at the level of the point of light, the point at which everything that looks at me is situated" (95). The sardine tin here presentifies that point which he calls the "object-gaze": the point from which the Other looks at me, prior to my looking back at him. It was from the memory of that scene that he deduced the object-gaze.

7 For this, Lacan is indebted to Merleau-Ponty and his idea of the visibility of things in his Phenomenology of Perception:

The lighting directs my gaze and causes me to see the object, so that in a sense it knows and sees the object. If I imagine a theatre with no audience in which the curtain rises upon illuminated scenery, I have the impression that the spectacle is in itself visible or ready to be seen, and that the light which probes the back and foreground, accentuating the shadows and permeating the scene through and through, realizes before us some kind of vision. (Merleau-Ponty 278)

Commenting on this passage and its influence on Lacan as he developed his theory of the gaze, Jacques-Alain Miller writes:

This is about a supplementary gaze which is always there - to take up MerleauPonty's example - and which is contained in visibility itself. In addition to that vision which another may have of me, there is the supplementary gaze of the Other, of the hidden Other. One may glimpse it when the light not only offers a field of visibility but also, simultaneously, focuses on a luminous spot which may figure the gaze, which incarnates for a moment the all-seeing gaze of the big Other ${ }^{5}$.

What this analysis brings out is that Lacan's object-gaze is the gaze of the big Other. Should that evanescent spot, briefly illuminated and glimpsed, become a fixture in the field of vision, then the subject could be assigned only one position, that of paranoia: under the gaze of a malevolent Big Other/Brother.

It is essential to understand that the normal subjective position is not that of paranoia: the Other may look at me, but does not see me. Thomasin may be threatened by the intrusive gaze of watchers as she sleeps in the reddleman's van, but she remains unharmed by that "watchful intentness". Visibility is no more than a potentiality. The object-gaze is but an evanescent point that may be briefly glimpsed, not a permanent all-seeing eye. Lacan defined the gaze as the "object" of the scopic drive, as one of the forms assumed by objet petit $a^{6}$. From which one may infer that the object-gaze, like objet petit $a$, is an object which is forever missing, "a pure deficit in the symbolic order that does not have any imaginary protrusion to fill it out [...] a vacuum, sucking other objects into its place" (Kaye 56). It is felt as an absence rather than as a presence, it is "extracted" from our reality. Its "extraction", normally effected by symbolic castration, is what gives coherence to our reality:

Lacan pointed out that the consistency of our "experience of reality" depends on the exclusion of what he calls the objet petit a from it: in order for us to have normal "access to reality", something must be excluded, "primordially repressed". In psychosis, this exclusion is undone: the object (in this case, the gaze or voice) is included in reality, the outcome of which, of course, is the disintegration of our "sense of reality", the loss of reality. (Žižek 1996, 91) 


\section{The Medusean eye in Hardy's fiction}

11 The best illustration that can be given to make all this clear is the one used by Lacan himself: the anamorphosis in Holbein's famous painting, The Ambassadors ${ }^{7}$ (see comment in Ramel 2015, 85-86 \& 89). But let us now turn to Hardy, who sometimes uses spatial constructions that "extract" the object-gaze, in likeness to the effect produced by The Ambassadors. In Far from the Madding Crowd, the presence / absence of the object-gaze is felt from the beginning: immediately after the sheep have fallen off the edge of the cliff, Oak looks down into the precipice, then shifts his gaze to survey the whole scene. Something on the outer margin of the pit catches his eye, it is a pond which looks like "a dead man's eye". But the eye - the gaze of the Other - is not staring Oak in the face, it is "attenuated" by a particular construction of space:

By the outer margin of the pit was an oval pond, and over it hung the attenuated skeleton of a chrome-yellow moon which had only a few days to last-the morning star dogging her on the left hand. The pool glittered like a dead man's eye, and as the world awoke a breeze blew, shaking and elongating the reflection of the moon without breaking it, and turning the image of the star to a phosphoric streak upon the water (Hardy 1986, 33).

The frontal view of the "dead man's eye" is avoided by the pond having been placed on the edge of the scene - like Holbein's hollow bone -, on the frame of the picture. ${ }^{8}$ The pond is "oval", as if distorted by the gaze of the onlooker, who looks "awry" to see it. At the beginning of the description, death is figured by the moon as a "skeleton" - a memento mori, reminding Oak of the vanity of terrestrial things, as it only has a few more days to last. The skeleton is "attenuated" because the moon is on the wane, but the adjective also suggests that the horror is somehow screened, kept at a distance. Then we are shown the pond as a dead eye, and the "skeleton" of the moon comes to be reflected on the surface of the water. Death is now but a reflection, some object being interposed between its horror and the onlooker's eye. The breeze which starts blowing shakes and "elongates" the reflection of the moon, turning it into a "phosphoric streak upon the water" - an image which conveys the idea of some will-o'-the-wisp exhaled from the phosphorus of skeletons. In that uncanny object, characterized by its "particular stretching" (Hardy 1986, 87), by its "pulsatile", "spread out", uncertain quality (89), we recognize the "anamorphic ghost" that Lacan writes about, the death's head which looks at you from its empty sockets in Holbein's Ambassadors, and gives figure to the unrepresentable objectgaze.

Hardy's talent here lies in the construction of a picture that both shows the object-gaze and excludes it from the visual field: there is "more than meets the eye" in the anamorphosis, the split between the eye and the gaze is represented. To this scene one should oppose the passage in which Boldwood receives the Valentine card, whose effect is the exact reverse of that of anamorphosis. First, the card is a little surplus object - an incongruous thing which Bathsheba does not know what to do with, until she decides to send it to Boldwood, the only man who never looks at her. The Valentine finds its way to Boldwood's parlour, where it is placed on the wings of an eagle surmounting the timepiece on the mantel-shelf. The feminine has thus intruded into the home of the hardened bachelor - the feminine as enigmatic, unrepresentable ${ }^{9}$, radically Other, especially to such a man as Boldwood. The alien, incongruous object then starts to exert a fascination on him: "Here the bachelor's gaze was continually fastening itself till the large red seal 
became as a blot of blood on the retina of his eye" (Hardy 1986, 80). The red seal enters Boldwood's eye until it turns into a bloodstain on his retina, as if the wax and the blood on the retina became one and the same substance. Boldwood's eye looking steadfastly at the red seal becomes the thing it is looking at, while the red seal becomes the eye staring at it. The split between the eye and the gaze is annuled: the gaze of the Other has entered Boldwood at the very point from which he sees. The Valentine has become Boldwood's unheimlich double, and its voice, which orders him to marry the anonymous sender, logically becomes one with Boldwood's own voice, as the farmer repeats its injunction: “'Marry me,' he said aloud" (81). Boldwood conflates the enunciation of the Valentine and his own.

14 We should also note that the construction of space in this scene is different from that of anamorphosis. We have seen that the Valentine is first placed on the mantel-shelf. Later, when Boldwood goes to bed, he moves the Valentine to the corner of the looking-glass, sticking it in the frame of the glass. So far, the "insistent red seal" has been staring at Boldwood from the periphery of his visual space. Suddenly Boldwood's attention is drawn towards his own reflection in the mirror; the eye is no longer peripheral, it has migrated to the centre of the mirror: "The solemn and reserved yeoman [...] caught sight of his reflected features, wan in expression, and insubstantial in form. He saw how closely compressed was his mouth, and that his eyes were wide-spread and vacant" (Hardy 1986, 81). It is Boldwood's death's-head which now appears in the looking-glass, staring him in the face from the eyes of a dead man, which Boldwood recognizes as his own yet perceives as totally strange. This uncanny encounter between Boldwood and his double reflected in the mirror cannot be reduced to a symmetrical relation for, as Žižek argues, the double is not just an imaginary other, the same as me: it is an image of "radical otherness"; "the double is the same as me, yet totally strange; his sameness all the more accentuates his uncanniness". Žižek goes a step further by arguing that "at its most fundamental, the double embodies the phantom-like Thing in me [...] In my double, I don't simply encounter myself (my mirror image), but first of all what is 'in me more than myself [...] a pure substance of enjoyment exempted from the circuit of generation and corruption" (Žižek 2001, 125). The double, writes Žižek, is "the double qua Thing" (126).

15 A few words are necessary here to clarify Žižek's formula, "the double qua Thing". For Lacan "The Thing" (das Ding in Freudian terms) stands for what is most interior to the psyche ("in me more than myself"), and for what is most exterior to it. Lacan says it is "extimate" to the subject (Lacan 2008, 87-88) ${ }^{10}$. The Thing is "the absolute Other of the subject, that one is supposed to find again" (63) - as such, it is the primordial object of desire, the irreplaceable "object-cause" that the subject craves for. At the same time, it is a fantasy of perfect unity, where the subject dissolves into the Other and becomes one with it. So that "The Thing" is both what is most alien to the subject, and what represents his innermost being. Exactly like the image which the mirror sends back to Boldwood, which is both his own self and a figure of radical Otherness. The Thing is fantasized as the origin, the primeval unity ${ }^{11}$ to which every human being aspires to return, but never reaches - indeed Lacan equates it with "the maternal thing" $(81)^{12}$. As the ultimate object of desire, the Thing is a figure of perfect jouissance - but reaching it would put an end to desire and to life.

16 To what extent is Žižek's analysis relevant to Boldwood facing his double in the mirror? In particular, can it be argued that "the double qua Thing" is to Boldwood "a pure substance of enjoyment"? When the red wax and the man's retina become consubstantial, 
is that jouissance? For one thing, the Valentine with its red seal, drawing Boldwood like a magnet, indicates that Boldwood's desire is involved in a scene full of sexual undertones for instance the word "curve" is used with reference to handwriting but also to a woman's body (see Ramel 2016, 7-8). What desire, then? A desire for a particular woman? No, for Boldwood does not even know who wrote the Valentine. Desire is kindled here by the mystery of the origin of the anonymous letter, as if the fascination were caused by the opacity of what Pascal Quignard calls the "sexual night" (see Quignard) - the unfathomable mystery of the womb wherein everyone fancies lies his/her origin. Indeed the word "origin" occurs three times on two pages (Hardy 1886, 80-81). And we know that Boldwood will seek the "original" of the woman who wrote the message, and pursue the unique, primordial object-cause of his desire with unflinching determination. Undoubtedly, it is "The Thing" that Boldwood is concerned with. But why then should his vision of the woman writing give way to the vision of his own death's head reflected in the mirror? Why is the image of the alluring red seal overturned to reveal the horror lurking just behind? Here Hardy speaks some truth about human desire at its most fundamental: for the drive towards the Thing is another name for the death drive. Death is the fate that awaits whoever attempts a backward course to his/her origin, but it is also his / her truest and most intimate desire. So after all Žižek's theorizing about the double is perfectly relevant here: the double is indeed "the double qua Thing", "a pure substance of enjoyment" which, one might say, is "in Boldwood more than himself". The scene, in its subtle mixing of sexuality and the death-drive, is definitely about jouissance in the Lacanian sense of the term.

17 If the double stands for radical Otherness, the Otherness of the Thing, it logically ensues that the eyes in the mirror embody the gaze of the Other - that is to say, in Lacanian words, the object-gaze. The same inference can be made about the red seal turned into a mirror-image of the eye staring at it $^{13}$. And also about Boldwood's own eyes. That idea is developed by Žižek in a passage about the double:

When I find myself face to face with my double, when I "encounter myself" among the objects, when "I myself" qua subject appear "out there", what am I at that precise moment as the one who looks at it, as a witness to myself? Precisely the gaze qua object: the horror of coming face to face with my double is that this encounter reduces me to the object-gaze. (Žižek 2001, 126)

18 At this point, when the eye and the Other's gaze coincide, "when the gaze qua object is no longer the elusive blind spot in the field of the visible but is included in this field, one meets one's own death". For indeed "'seeing oneself looking' [se voir voyant], unmistakably stands for death" (Žižek 1996, 94). In the uncanny encounter between a man and his double (Doppelgänger), "the double strangely seems always to look askew, never to return our gaze by looking straight into our eyes - the moment he were to do it, our life would be over" (94). The die is cast for Boldwood from now on: when the eye and the gaze meet in an awful conflation, the gaze turns Medusean, and only death can ensue - Boldwood will not actually die, since he is reprieved, but he is symbolically dead ("he walked the world no more", Hardy 1986, 290).

Thus it appears that the "evil eye" is the form assumed by the object-gaze when it ceases to be a vacillating, evanescent presence / absence. In The Return of the Native, the organization of space at the beginning of the novel is careful to show the split between the eye and the gaze ${ }^{14}$, in particular in chapter III ("The Custom of the Country") where the flames of the bonfire on Egdon Heath throw an unstable light on the individuals standing round and produce an effect comparable to that of anamorphosis. But rather 
than dwelling on this, I will focus on the scene in which Mrs Yeobright is literally killed by Eustacia's gaze, in a mortal face to face encounter. Clym's mother, wanting to make peace with her son, knocks at the door of his cottage, but Clym is asleep and does not hear anything, while Eustacia is in the compromising company of Wildeve. Eustacia does not at first open the door, so Mrs Yeobright walks away, thinking her son rejects her. But she has seen something that will ultimately kill her, she has indeed been "overlooked" (see Dillion \& Mallett): "I have seen [...] a woman's face looking at me through a windowpane" (Hardy 1990, 288). In her exchange on the heath with a little boy- Jimmy Nunsuch -, she explains to him that she has seen a "bad sight", to which the boy replies: "once when I went to Throope Great Pond to catch effets I seed myself looking up at myself, and I was frightened and jumped back like anything" (288). The "bad sight" for Jimmy was clearly a case of "seeing himself looking" - and we know by now that such an experience "unmistakably stands for death". The parallel made by the narrative between the "bad sight" encountered by Jimmy and that seen by Mrs Yeobright encourages us to believe that in the window of Clym's cottage, what Mrs Yeobright has seen is not just her daughter-in-law refusing to let her in, but her own mirror-image, her true double - such a reading being of course perfectly consonant with Freudian analyses focusing on the mother's desire to supplant her daughter-in-law and have her son all to herself. A few pages further, after she has been stung by an adder and carried into a hut, so that her wound might be anointed by the liquid fat of an adder, she finds herself facing the animal about to be sacrificed. In a mirror-relation, the eye of the creature meets her own eye: "The live adder regarded the assembled group with a sinister look in its small black eye, and the beautiful brown and jet pattern, on its back seemed to intensify with indignation. Mrs Yeobright saw the creature, and the creature saw her: she quivered throughout, and averted her eyes" (297). Averting her eyes - like the man attempting to look askew to avoid looking straight into the eyes of his double - is to no avail. What is repeated here is the deadly face-to-face relation between her and Eustacia through the window-pane: the "small black eye" of the adder, "like a villainous sort of black currant" (297), which the villagers fear might "ill-wish" them (298), is of course a duplicate of Eustacia's "wild dark eyes" known for their "ill-wishing" power (48). The "scarlet speck" which appears on Mrs Yeobright's foot (296-297) unmistakably identifies her with Eustacia who, in an earlier scene, showed to Clym "a scarlet little puncture", "a bright red spot" on her round white arm (186-187). This confirms my interpretation of Mrs Yeobright's "bad sight": what she has seen in the window-frame is her own double, she has seen herself looking at herself. Like Žižek's Doppelgänger, she finds herself "at the very point of a pure gaze" ${ }^{15}$. In this conflation of eye and gaze, she can only meet her death. The "evil eye" that has killed her, the Medusa-like gaze of her daughter-in-law, is no other than the object-gaze coinciding with her own eye.

20 Another mirror-scene takes place a little later. Johnny Nunsuch has just revealed to Clym the circumstances of his mother's death. Clym comes home in a rage and arrives behind Eustacia, who is standing before a looking-glass:

[...] when he opened the door she was standing before the looking glass in her nightdress, the ends of her hair gathered into one hand, with which she was coiling the whole mass round her head, previous to beginning toilette operations. She was not a woman given to speaking first at a meeting, and she allowed Clym to walk across in silence, without turning her head. He came behind her, and she saw his face in the glass. It was ashy, haggard, and terrible. Instead of starting towards him in sorrowful surprise [...] she remained motionless, looking at him in the glass. And while she looked the carmine flush with which warmth and sound sleep had 
suffused her cheeks and neck dissolved from view, and the deathlike pallor in his face flew across into hers. He was close enough to see this, and the sight instigated his tongue.

'You know what is the matter,' he said huskily. 'I see it in your face' (Hardy 1990, 328 ).

Clym has caught in the mirror-image of Eustacia what normally eludes the eye's grasp, the object-gaze which is "more than meets the eye" (Žižek 2001, 127). The logic of the double prevails here: the subject's eye and the Other's gaze coincide, Eustacia sees herself looking, and Clym sees her seeing herself looking. In this uncanny encounter, Clym sees Eustacia's eye looking at her mirror-image, and Eustacia sees Clym's gaze peering into the mirror and seeing her at the very point from which she sees. The mirror has indeed become a looking glass, which both reflects and sees - unlike Aragon's "mirror", and unlike the mirror in Lacan's mirror-stage. Clym knows that she knows that he knows that she knows, etc. Clym's eye here is not blind, not empty, it is inhabited by Eustacia's real presence. Such an eye/gaze is Medusean: Eustacia does not turn, her head, she remains motionless, petrified. Both Clym and Eustacia seem to have been turned to stone.

So Boldwood and Eustacia are both confronted to "looking-glasses" inhabited by the presence of the Other. "The Withered Arm" (Hardy 1988, 52-78) stages a similar mirrorrelation between Rhoda and Gertrude, "the supplanted woman" (Rhoda) having found her double in Gertrude, the wife of Farmer Lodge ${ }^{16}$. In the attempt to find a cure for Gertrude's "withered arm", Rhoda and Gertrude visit conjuror Trendle, who shows Gertrude a glass filled with a strange mixture - in fact a mixture of water and egg-white where, he says, she might be able to see an image of the "enemy" causing her trouble. Rhoda, who has been told to wait outside, sees all the proceedings, for the door has remained ajar, and then the glass is brought close to the window. She is "overlooking" the scene, indeed she is the focaliser in the passage, which is important. What does Gertrude see in the glass? The glass functions as a "looking-glass" - in the sense of "a glass used for looking" -, but also as a mirror, for it sends to Gertrude an image of Rhoda, the other woman looking at her in the glass. But a very special mirror, which is also a "looking glass" - without a hyphen -, a glass looking at Gertrude, now exposed to the gaze of the Other - the other woman, the "enemy" -, that is to say to the object-gaze. Indeed "the opaline hue of the egg fluid" staring Gertrude in the face is strongly reminiscent of "the uneasy depthless white" of a blind man's eyes, which, according to Žižek is "an exemplary case" of the gaze qua object: "The exemplary case of the gaze qua object is a blind man's eyes, i.e. eyes which do not see (we experience the gaze qua object when a partner in conversation suddenly takes off his black glasses, exposing us to the uneasy depthless white of his eyes") (Žižek 2001, 117) ${ }^{17}$. It is as though the uneasy mixture of egg-white and water had turned into the white of an eye, an eye without a pupil ${ }^{18}$ - a figure given to the unspecularisable object-gaze. At the same time, the "looking glass" also functions as a mirror held to Gertrude, for as she sees her double in the mirror, she also sees herself. She sees herself seeing herself seeing. As for Rhoda, she sees herself being seen by Gertrude, and she sees herself seeing herself being seen by Gertrude, for the specular relation implies reversibility - indeed the same pallor creeps over the faces of the two women. The gaze of the Other "enters" them, reaches them at the innermost point from which they see. The shapeless, turbid image reflected by the looking-glass is "extimate" to Gertrude/Rhoda: both intimate, and alien to them, like Žižek's Döppelganger, and like Boldwood's mirror-image. The villagers are right to believe that Gertrude's misfortunes have been caused by her being "overlooked" (Hardy 1988, 66): for when the eye and the 
gaze coincide - in popular superstitions and in works of fiction - the encounter is always mortal. That is what tradition calls the "evil eye".

\section{BIBLIOGRAPHY}

André, Serge, Que veut une femme, Paris : Navarin, 1986.

Braunstein, Nestor, La jouissance, un concept lacanien, Paris : Point Hors Ligne, 1992.

Bullen, J. B., The Expressive Eye, Oxford: Clarendon Press, 1986.

Dillion, Jacqueline \& Phillip Mallett, “'The Evil Eye': Looking and Overlooking in The Return of the Native", Rivista di Studi Vittoriani 38-39 (2014-2015), 7-28. Also published in The Thomas Hardy Journal XXXI (Autumn 2015), 89-107.

Dillion, Jacqueline, Thomas Hardy: Folklore and Resistance, London: Palgrave Macmillan, 2016.

Hardy, Florence Emily, The Early Life of Thomas Hardy 1840-1891 (1928), Cambridge: CUP, 2011.

Hardy, Thomas, Far from the Madding Crowd (1874), ed. Robert C. Schweik, W.W. Norton, NewYork, 1986.

Hardy, Thomas, “The Withered Arm” (1888), Collected Short Stories, intro. Desmond Hawkins, London: Macmillan, 1988, 52-78.

Hardy, Thomas, The Return of the Native (1878), Oxford: World's Classics, 1990.

Hardy, Thomas, Tess of the d'Urbervilles (1891), Oxford: World's Classics, 1991.

Kaye, Sarah, Slavoj Žižek: A Critical Introduction, Cambridge: Polity Press, 2003.

Lacan, Jacques, Le Séminaire XI, Les quatre concepts fondamentaux de la psychanalyse, Paris : Seuil, 1973.

Lacan, Jacques, The Seminar, Book XI (1979), trans. Alan Sheridan, The Four Fundamental Concepts of Psychoanalysis, London: Peregrine Books, 1986.

Lacan, Jacques, Autres écrits, Paris : Seuil, 2001.

Lacan, Jacques, Le Séminaire X, L'angoisse, Paris : Seuil, 2004.

Lacan, Jacques, Le Séminaire XVI, D'un autre à l'Autre, Paris : Seuil, 2006.

Lacan, Jacques, The Seminar, Book VII (1986), trans. Dennis Porter, The Ethics of Psychoanalysis, Abingdon: Routledge, 2008.

Louvel, Liliane, Poetics of the Iconotext, ed. Karen Jacobs, trans. Laurence Petit, Farnham: Ashgate, 2011.

Merleau-Ponty, Maurice, Phenomenology of Perception, London: Psychology Press (Routledge Classics Series), 1962.

Miller, Jacques-Alain, “L'image du corps en psychanalyse”, La Cause freudienne 68.1 (2008) :94-104.

Miller, Joseph Hillis. Fiction and Repetition, Cambridge: Harvard UP, 1982. 
Miller, Joseph Hillis, Distance and Desire, Cambridge (Mass.): Belknap Press of Harvard UP, 1970.

Morgan, Rosemarie, Women and Sexuality in the Novels of Thomas Hardy, London \& New York: Routledge, 1991.

Quignard, Pascal, La nuit sexuelle, Paris : Flammarion, 2007.

Ramel, Annie, “The 'Passion for Particularity' in The Return of the Native", Miranda [Online] 1 (2010): <http://journals.openedition.org/miranda/719> (last accessed 10 Apr 2018).

Ramel, Annie, “The Scapegoat in Hardy's Tragic Novels: Revisiting Ancient Theory”, Gramma 18 (2010): 81-96.

Ramel, Annie, The Madder Stain: A Psychanalytic Reading of Thomas Hardy, Leiden: Brill Rodopi, 2015. Ramel, Annie, "Bathsheba's Lost Hat and Metonymic Substitution: Objects in Far from the Madding Crowd," FATHOM [Online] 3 (2016), <http://journals.openedition.org/fathom/504> (last accessed 10 Apr 2018).

Sartre, Jean-Paul, Being and Nothingness: An Essay on Phenomenological Ontology (1943), trans. Hazel E. Barnes, London: Methuen, 1958.

Wajcman, Gérard, L'CFil absolu, Paris : Denoël, 2010.

Žižek, Slavoj, “'I hear you with my eyes': or, The Invisible Master”, Gaze and Voice as Love Objects, eds. Slavoj Žižek \& Renata Salecl, Durham \& London: Duke UP, 1996, 90-126.

Žižek, Slavoj, Enjoy your Symptom, New York \& London: Routledge, 2001.

\section{NOTES}

1. Though of course responding to the other's gaze is essential in building intersubjective relations. Lacan's "mirror-stage" provides the infant with a unified image of his/her self but also, simultaneously, introduces him to social relations (i.e. to the symbolic world) because the supporting role of other human beings (encouraging him to recognize himself/herself in the mirror-image) is an essential part in the process. The infant sees his/her own image and also sees the supporting other looking at it and identifying him/her with it.

2. The actual translation in the Peregrine Book (Lacan, Jacques. The Four Fundamental Concepts of Psychanalysis, translated by Alan Sheridan (1977) from Le Séminaire, XI, "Les quatre concepts fondamentaux de la psychanalyse", reprinted in Peregrine Books, London, 1986) is: "you never look at me from the place from which I see you", which does not make sense, and is erroneous - the French being "jamais tu ne me regardes là où je te vois" (Lacan 1973, 95). I have taken the liberty of correcting the translation.

3. For Sartre, the gaze is that which enables the subject to realize that the Other is also a subject: "My fundamental connection with the Other-as-subject must be able to be referred back to my permanent possibility of being seen by the Other" (Sartre 256). Lacan went along with Sartre in his early seminars, his conception of the mirror-stage is perfectly consonant with such a view. It was only in 1964 that he developed his own conception of the gaze as objet petit $a$ and then took issue with Sartre on this question (Lacan 1973, 84).

4. Lacan quotes this poem twice in The Seminar XI, first as an introduction to his second chapter, "The Freudian Unconscious and ours", then to introduce his seventh chapter on "Anamorphosis":

Vainement ton image arrive à ma rencontre Et ne m'entre où je suis qui seulement la montre 
Toi te tournant vers moi tu ne saurais trouver Au mur de mon regard que ton ombre rêvée Je suis ce malheureux comparable aux miroirs Qui peuvent réfléchir mais ne peuvent pas voir Comme eux mon œil est vide et comme eux habité De l'absence de toi qui fait sa cécité

(Louis Aragon, Le Fou d'Elsa, “Contre-chant", 1963, quoted and translated in Lacan 1986, 17).

5. "Il s'agit d'un regard supplémentaire qu'il y a toujours - pour reprendre l'exemple de MerleauPonty - et qui est le regard contenu dans la visibilité même. Qu'en plus de la vision qu'un autre peut avoir de moi, il y a le regard supplémentaire de l'Autre, de l'Autre caché. On peut percevoir cela quand la lumière non seulement offre un champ de visibilité mais se concentre en même temps sur un point lumineux qui peut avoir valeur de regard, qui incarne un moment le regard omnivoyant du grand Autre" (Miller 2008, 103, my translation).

6. "Of the Gaze as Objet Petit $a$ " is the title of the second part of The Seminar XI, given by Lacan in 1964. Lacan defines the gaze as an object, which he adds to the four drive objects listed by Freud. The object-voice is another object added by Lacan, gaze and voice being interrelated forms of objet $a$.

7. The Ambassadors is reproduced on the front-cover of Lacan's XIth Seminar. See chap. VII, entitled "Anamorphosis", 79-90. In Holbein's painting, the anamorphic object, the death's head, is "extracted" from the visual field by being placed at the bottom of the picture, where it is distorted and unrecognizable. At first, all you see is some sort of cuttlebone, until an oblique gaze allows you to catch a glimpse of the death's head.

8. J.B. Bullen has shown the "pictorial" quality of Hardy's descriptions (Bullen 6). Liliane Louvel, in Poetics of the Iconotext, has developed the concept of the "painting-effect" in texts, "an illusionistic effect so powerful that painting seems to haunt the text despite the absence of any direct reference to painting in general or to a particular painting" (Louvel 90).

9. "L'irreprésentable de la féminité" ("the unrepresentable of femininity", André 263).

10. Lacan first introduced the word "extime" in his XVIth Seminar (Lacan 2006, 249).

11. Such primeval unity, conceived as anterior to subjective division, never existed: it is a mere effect of language, posterior to symbolic castration (Braunstein 78-79).

12. "Well now, the step taken by Freud [...] is to show that there is no Sovereign Good - that the Sovereign Good, which is das Ding, which is the mother, is also the object of incest, is a forbidden good, and that there is no other good" (Lacan 2008, 85).

13. The red stain as a representation of the object-gaze should not surprise us, for Lacan has argued that the first model of the gaze is the stain: "[...] le premier modèle du regard est la tache" (Lacan 2001). The red stain as a figure of the object-gaze is the key-idea in my book on Thomas Hardy, The Madder Stain (Ramel 2015).

14. The tumulus from which Eustacia looks at Wildeve's lit window through her telescope is some distance away from the tumulus where she means to be reached by Wildeve's gaze (she keeps her private bonfire burning steadily there to attract his attention, Hardy 1990, 55).

15. "As a rule one focuses on the horror of being the object of some invisible, unfathomable, panoptical gaze (the 'someone-is-watching-me' motif) - yet it is a far more unbearable experience to find oneself at the very point of a pure gaze" (Žižek 2001, 126).

16. Rhoda's boy stares at Gertrude, as if he "would read her through and through" (Hardy 1988, 54), and gives a full report to his mother, providing her with a mental image of Mrs Lodge "that was realistic as a photograph" (57). A photograph that works as a mirror-image, for what Rhoda seeks in it is her own image. Rhoda will end up being "wrinkled" (78) in perfect likeness to Gertrude. 
17. In this Žižek is merely following Lacan: "Qu'est-ce qui nous regarde? Le blanc de l'oeil de l'aveugle, par exemple" (Lacan 2004, 293).

18. The pupil for Lacan is a structural "hole", a blind spot which allows the subject to be "elided as subject of the geometral plane" (Lacan 1986, 108), i.e. which maintains the split between eye and gaze.

\section{ABSTRACTS}

The eye in Thomas Hardy's fiction is often felt as a menace, like the "oval pond" in Far from the Madding Crowd, glittering "like a dead man's eye". The unblinking eye can be an "evil eye", full of voracity, endowed with a Medusean power, the power to petrify or to kill. Indeed eyes do kill in Hardy's stories: Mrs Yeobright is killed by the "bad sight" of her daughter-in-law looking at her from a window and not opening the door - the "small black eye" of the live adder later regarding her being a duplicate of Eustacia's "ill-wishing" dark eyes. At what point does the gaze, which normally makes manifest the "positive, dynamic and productive dimension of desire" (Jane Thomas, Thomas Hardy and Desire: Conceptions of the Self, Basingstoke: Palgrave Macmillan, 2013, back cover) turn Medusean? Jacques Lacan's concept of the unspecularizable "object-gaze" will help us to understand this, and throw a new light on the fictional use which Hardy made of "the evil eye" - a superstition known in Dorset as "overlooking".

L'œil dans la fiction de Thomas Hardy est souvent perçu comme menace : c'est la cas de l'étang ovale éclairé par la lune qui luit "comme l'œil d'un mort" dans Far from the Madding Crowd. L'œil fixe, qui ne cille pas, peut être "le mauvais œil", plein de voracité, doué d'un pouvoir méduséen, le pouvoir de pétrifier et de tuer. En vérité, l'œil tue dans la fiction de Hardy : Mrs Yeobright est tuée par un "spectacle" au pouvoir maléfique ("a bad sight"), la vue de sa belle-fille qui la regarde par une fenêtre et ne lui ouvre pas la porte - le "petit œil noir" de la vipère qui la regarde plus tard n'étant autre qu'une réplique de l'œil noir de Eustacia, capable de jeter le mauvais sort. À quel moment passe-t-on du regard porteur de désir, qui en rend manifeste la dimension "positive, dynamique et productive" (Jane Thomas, Thomas Hardy and Desire: Conceptions of the Self, Basingstoke: Palgrave Macmillan, 2013) au regard méduséen? Le concept lacanien de "l'objetregard" nous aidera à comprendre cela, et éclairera d'un jour nouveau l'utilisation fictionnelle que fait Hardy de cette superstition connue dans le Dorset comme "overlooking" ("jeter le mauvais œil").

\section{INDEX}

Keywords: evil eye, desire, gaze, gaze qua object, overlook, anamorphosis, double, mirror oeuvrecitee Far from the Madding Crowd, Return of the Native (The), Withered Arm (The)

Mots-clés: mauvais œil, regard, désir, objet-regard, anamorphose, double, miroir 


\section{AUTHOR}

\section{ANNIE RAMEL}

Annie Ramel, professor emeritus at Université Lumière-Lyon 2, is the president of FATHOM (French Association for Thomas Hardy Studies). Her publications include: Great Expectations, le père ou le pire (Messene, 2000), articles on Charles Dickens, Henry James, George Eliot, Oscar Wilde, Thomas Hardy. She edited or co-edited several publications: Rewriting/Reprising: the Paradoxes of Intertextuality, the first three volumes of the e-journal FATHOM, as well as the volume on "Liminality" of The Hardy Review (Spring 2013). She has published The Madder Stain: A Psychoanalytic Reading of Thomas Hardy (Brill-Rodopi, 2015). 